\title{
Diagnóstico de la infección por el virus zika Diagnosis of Zika virus infection
}

\author{
César Cabezas ${ }^{1,2}$, Paquita García ${ }^{1}$ \\ ${ }^{1}$ Centro Nacional de Salud Pública, Instituto Nacional de Salud. \\ ${ }^{2}$ Facultad de Medicina San Fernando, Universidad Nacional Mayor de San Marcos.
}

\section{Correspondencia}

\section{César Cabezas Sánchez} ccabezas@ins.gob.pe

Recibido, 22 diciembre 2016

Evaluado, 13 enero 2017

Aceptado, 18 enero 2017

Ningún conflicto de interés Financiamiento: Propio

Citar como: Cabezas C, García P. Diagnóstico de la infección por el virus zika. An Fac med. 2017;78(1):89-93. DOI: http://dx.doi. org/10.15381/anales.v78i1.13028

\section{An Fac med. 2017;78(1):89-93 / http://dx.doi.org/10.15381/anales.v78i1.13028}

\section{Resumen}

El virus del zika es un virus ARN que puede tener como complicaciones de su infección al síndrome congénito y sindrome de Guillain Barré. Como hay otros arbovirus que cursan con fiebre y rash, es importante el enfoque sindrómico para orientar las pruebas y el diagnóstico de laboratorio.

Actualmente están disponibles el RT-PCR en tiempo real y el aislamiento viral, como estándares para el diagnóstico confirmatorio en los primeros dias de la infección.

Existen pruebas serológicas (ELISA, NP) para determinar anticuerpos IgM, pero hay el inconveniente de las reacciones cruzadas con otros flavivirus. Sin embargo, pueden utilizarse en ciertas circunstancias en la que no es posible contar con RT-PCR y hacer una interpretación adecuada.

Palabras clave. Virus Zika; Diagnóstico; Laboratorio.

\section{Abstract}

Zika virus is an RNA virus whose infection can have as complications congenital syndrome and Guillain Barré syndrome. As there are other arboviruses that present with fever and rash it is important to have a syndromic approach for testing and laboratory diagnosis.

Currently real time RT-PCR and virus isolation are available as standards for confirmatory diagnosis in the early days of infection.

The serological tests (ELISA, NP) to determine IgM antibodies have the disadvantage of cross-reactions with other flaviviruses, though they may be used in certain circumstances where it is not possible to have RT-PCR and a proper interpretation.

Keywords: Zika Virus; Diagnosis; Laboratory. 


\section{INTRODUCCIÓN}

El virus del zika (ZIKV) es un virus ARN que es transmitido principalmente a través de artrópodos y fue descubierto en primates en 1947, en un lugar llamado Zika en la selva de Uganda, mientras se hacía vigilancia de la fiebre amarilla ${ }^{(1)}$. No fue considerado mayormente como un problema de salud pública, hasta la aparición de brotes en el 2007 en Indonesia ${ }^{(2)}$, en el 2013 en Polinesia Francesa, asociada a síndrome de Guillain Barre ${ }^{(3)}$, y el 2015 en Brasil, con un extenso brote asociado a microcefalia ${ }^{(4,5)}$.

EI ZIKV pertenece a la familia Flaviviridae, género Flavivirus, al cual también pertenecen varios otros virus transmitidos por vectores relevantes para la salud humana, como el virus del dengue (DENV), el virus de la fiebre amarilla (YFV), el virus de la encefalitis japonesa (JEV), el virus del Nilo Occidental (VNO) y el virus de la encefalitis transmitida por garrapatas (TBEV). Además, un cuarto grupo de virus que solo se encuentran en los insectos es incluido en este género ${ }^{(6)}$.
El árbol filogenético del ZIKV está estrechamente relacionado con el virus del dengue y a clusters dentro del grupo de Spondweni (figura 1). Las cepas ZIKV tienen dos linajes principales, el linaje africano, que incluye cepas aisladas en África Central y Occidental, y el linaje asiático, que incluye cepas aisladas en el sudeste de Asia y el Pacífico y las procedentes de las Américas ${ }^{(7)}$.

Al igual que otros flavivirus, el ZIKV tiene una envoltura icosaédrica (figura 2) que contiene un sentido positivo, genoma de ARN monocatenario. El genoma codifica tres proteínas estructurales, es decir, proteínas de cápside (C), de membrana (prM) y de envoltura (E) que forma la partícula del virus con siete proteínas no estructurales (NS) (NS1, NS2A, NS2B, NS3, NS4A, NS4B y NS5) ${ }^{(8)}$.

Considerando que el ZIKV produce una infección que cursa con síndrome febril en un inicio, al igual que infecciones por otros arbovirus o incluso por otros agentes bacterianos y parasitarios, es importante tener un enfoque sindrómico para el diagnóstico, como se muestra

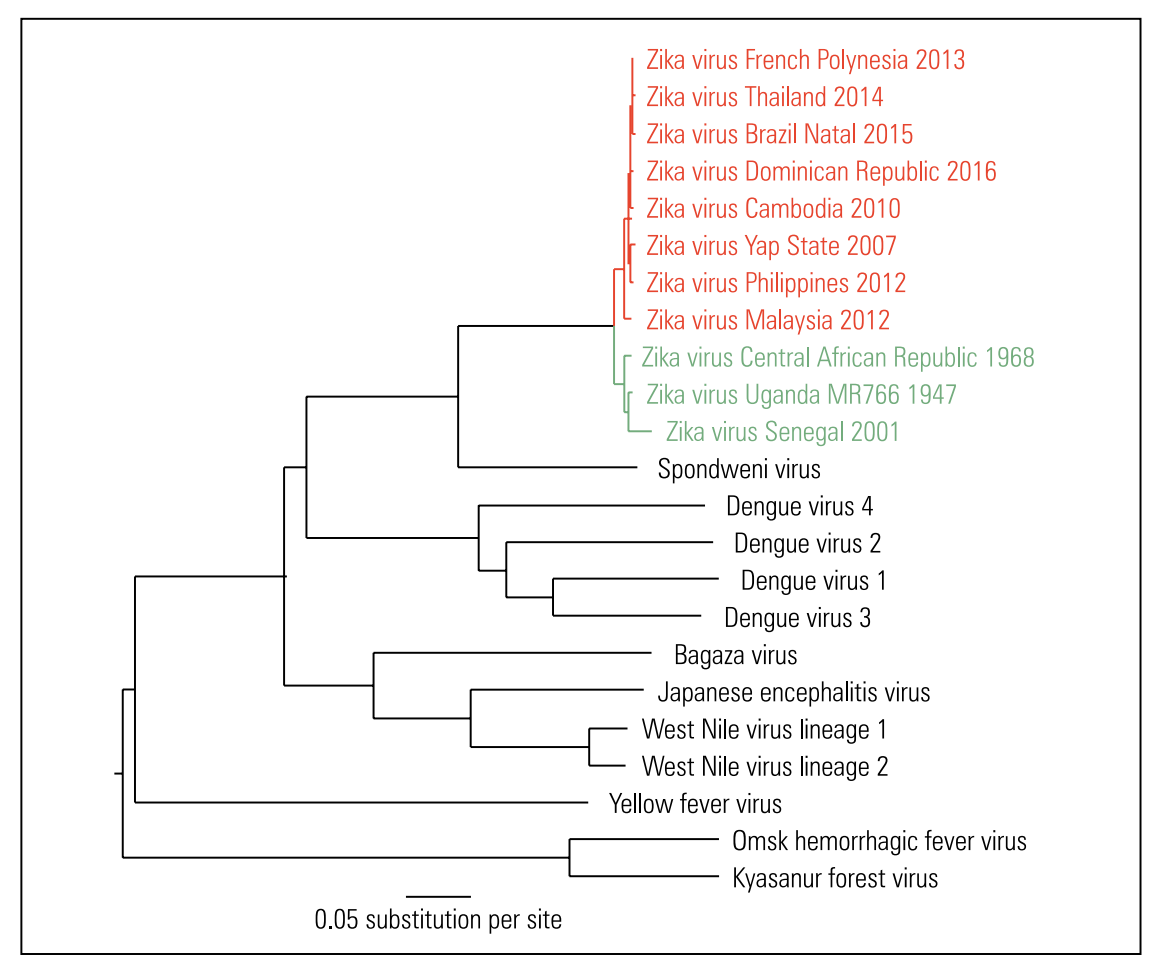

Figura 1. Árbol filogenético del virus zika ${ }^{(7)}$.

en la figura 3, lo que a su vez permita orientar las pruebas de laboratorio para el diagnóstico y las medidas terapéuticas de soporte y control.

Actualmente, para el diagnóstico del zika se cuenta con métodos directos para determinar el ARN viral, como es el RTPCR en tiempo real, las pruebas de amplificación de ácidos nucleicos (NAAT) y el aislamiento viral, los cuales se constituyen en el estándar para el diagnóstico definitivo, aunque más comúnmente se viene usando el RT-PCR en tiempo real. Además, se cuenta con pruebas serológicas para determinar anticuerpos IgM e IgG mediante la técnica de ELISA y la de neutralización en placas. Sin embargo, además de la limitada disponibilidad de pruebas para el diagnóstico de ZIKV, existen otros desafíos, como es la reacción cruzada de anticuerpos con otros flavivirus tipo dengue (DENV), virus del Nilo Occidental y fiebre amarilla, así como si la infección es actual o pasada, o incluso la vacunación con otro flavivirus causará a menudo falsos positivos ${ }^{(9,10)}$.

La determinación del ARN del ZIKV durante la infección aguda mediante el RT-PCR o por pruebas de amplificación de ácidos nucleicos (NAAT) proporciona resultados específicos. Sin embargo, esta prueba es útil en promedio en los primeros cinco días de la infección, que se agrega a que solo el $20 \%$ de pacientes presenta síntomas para sospecha de la infección.

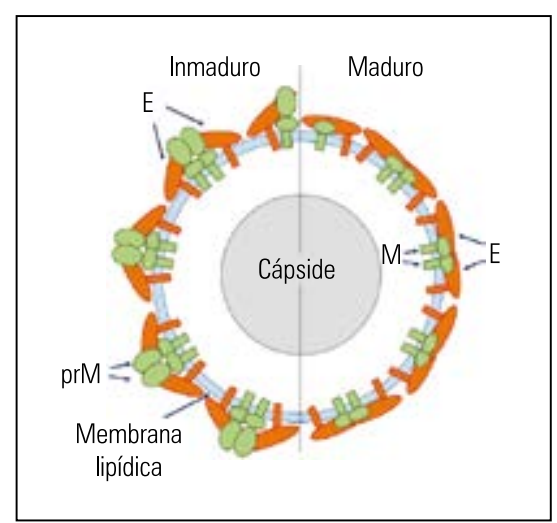

Figura 2. Estructura del virus zika ${ }^{(8)}$. psM=proteína de membrana, $\mathrm{M}=$ membrana, $\mathrm{E}=$ proteína de envoltura. 


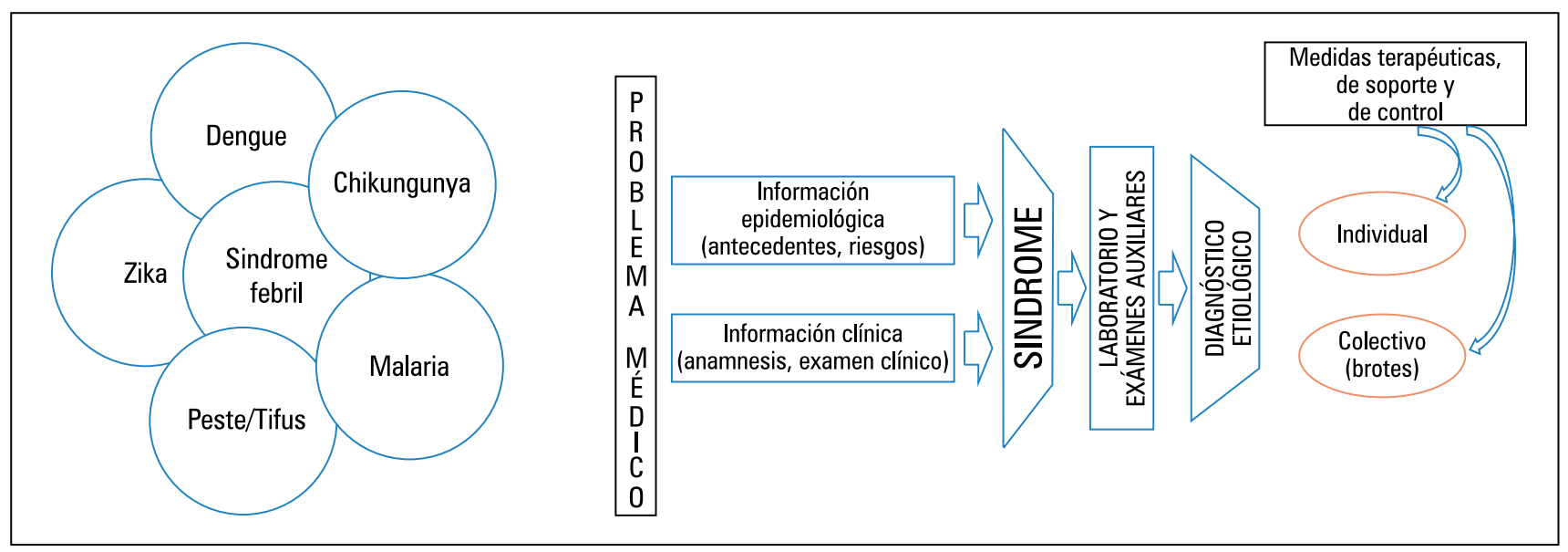

Figura 3. Enfoque sindrómico para el diagnóstico de enfermedades febriles.

Si bien el diagnóstico del zika está ligado a los laboratorios de salud pública, cada vez se hace necesario especialmente en mujeres gestantes que asisten a los servicios de salud, en quienes es una prioridad tener el diagnóstico por las implicancias que tiene la infección sobre el feto, en el que se puede producir un síndrome congénito como consecuencia de la infección intraútero.

Al momento, no existen kits comerciales validados para la determinación serológica de ZIKV, a lo que debemos agregar las reacciones cruzadas con otros flavivirus de anticuerpos IgM contra el zika ya mencionadas, e incluso en las pruebas de neutralización pueden presentarse reacciones cruzadas. Debido a que la se- rología es ampliamente utilizada para el diagnóstico y la vigilancia de DENV, debe tenerse en cuenta este aspecto para una adecuada interpretación de los resultados. La utilidad de la serología puede darse en casos de síndrome de Guillain Barré con resultado positivo a infección por flavivirus (IgM DENV-ZIKV positivo). Se debe considerar la poca frecuencia de esta complicación en infecciones por DENV, orientando el caso hacia ZIKV. En un recién nacido con algún síndrome congénito, la lgM positiva cobra un valor muy importante (en suero o en LCR) y es altamente sugestiva de infección intrauterina. Sin embargo, un resultado negativo NO descarta la infección, por lo que se debería intentar la detección en suero de la madre para buscar evidencia (11).

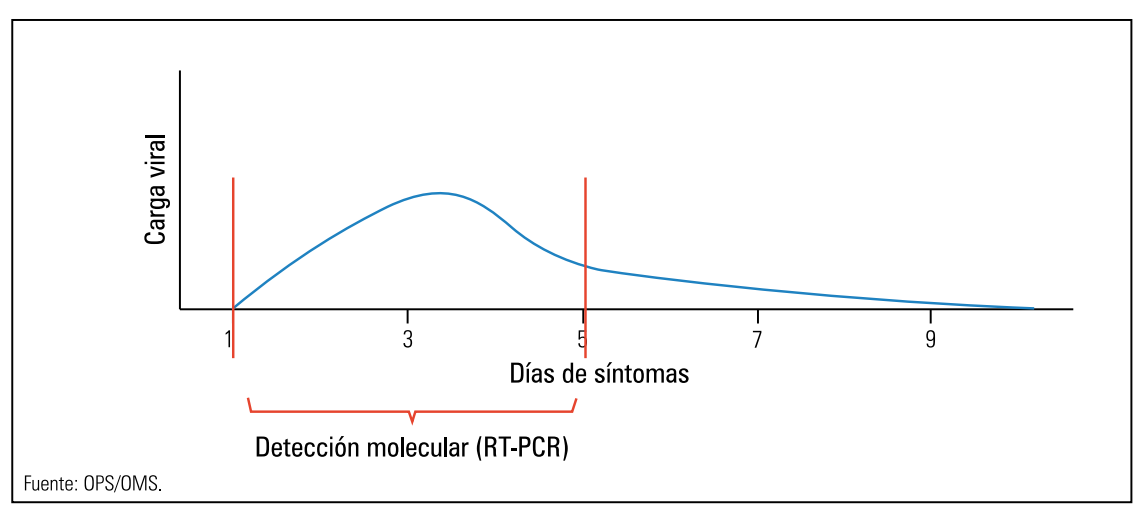

Figura 4. Tiempo de enfermedad y su relación para la determinación del ARN del ZIKV mediante RT-PCR en tiempo real en muestra de suero.
Para solicitar el examen de laboratorio que corresponda es necesario tener en cuenta la definición de caso sospechoso de enfermedad por el virus zika, como aquella persona que reside o visitó áreas epidémicas o endémicas en los últimos 14 días antes del inicio de síntomas, que presente exantema y al menos dos o más de los siguientes signos o síntomas: fiebre, generalmente $<38,5^{\circ} \mathrm{C}$, conjuntivitis (no purulenta/ hiperémica), artralgias, mialgia, edema periarticular.

Un caso sospechoso de enfermedad por virus zika en áreas sin casos autóctonos y sin presencia de vectores para la transmisión del virus, se considera al paciente que cumpla los criterios de caso sospechoso de enfermedad por virus zika, y que en las 2 semanas anteriores a la aparición de los síntomas tenga antecedente de residencia o viaje a un área con transmisión local del virus zika o con presencia de vectores; o tenga antecedente de contacto sexual sin protección en las 2 semanas previas a la aparición de los síntomas, con una persona que en las 8 semanas previas al contacto sexual tenga antecedente de residencia o viaje a un área con transmisión local del virus zika o con presencia de vectores.

Por otro lado, el caso confirmado de enfermedad por el virus zika es todo caso sospechoso de enfermedad por el virus zika que tenga resultado positivo a una o más de las siguientes pruebas: RT-PCR en tiempo real para ZIKV y/o aislamiento vi- 


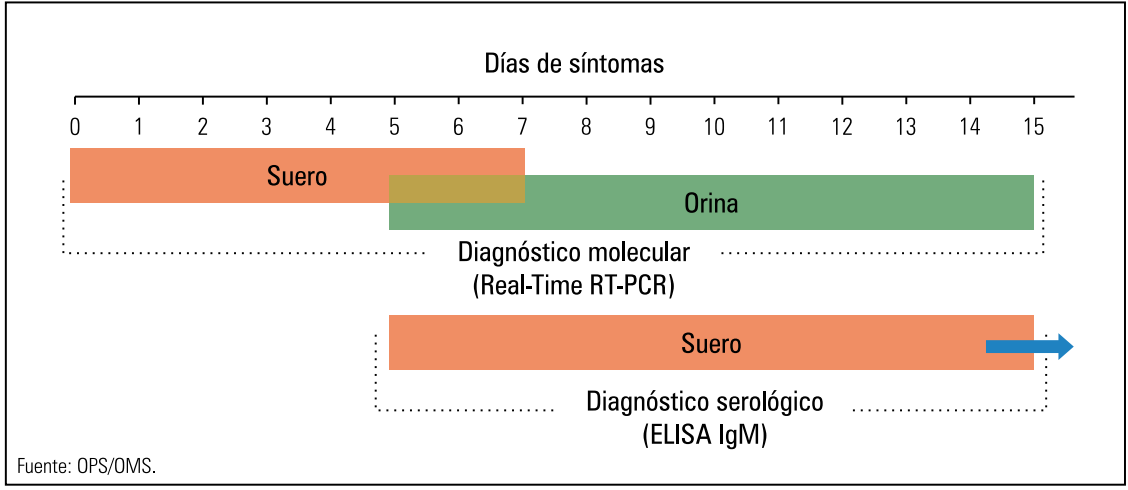

Figura 5. Tiempo de enfermedad y su relación para la determinación del ARN del ZIKV por RT-PCR en suero, orina y de IgM en suero mediante ELISA.

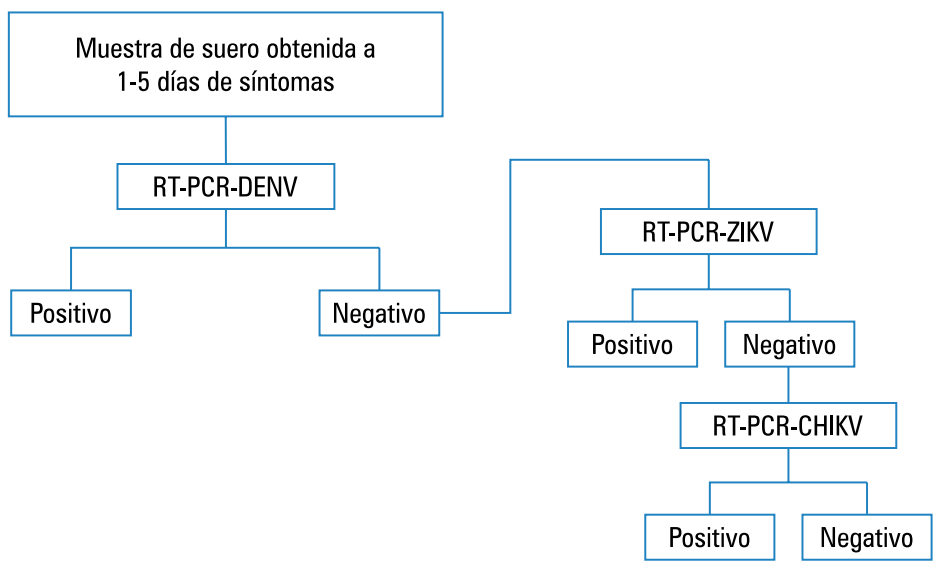

Figura 6. Algoritmo para diagnóstico diferencial de zika, dengue y chikungunya ${ }^{(11)}$.

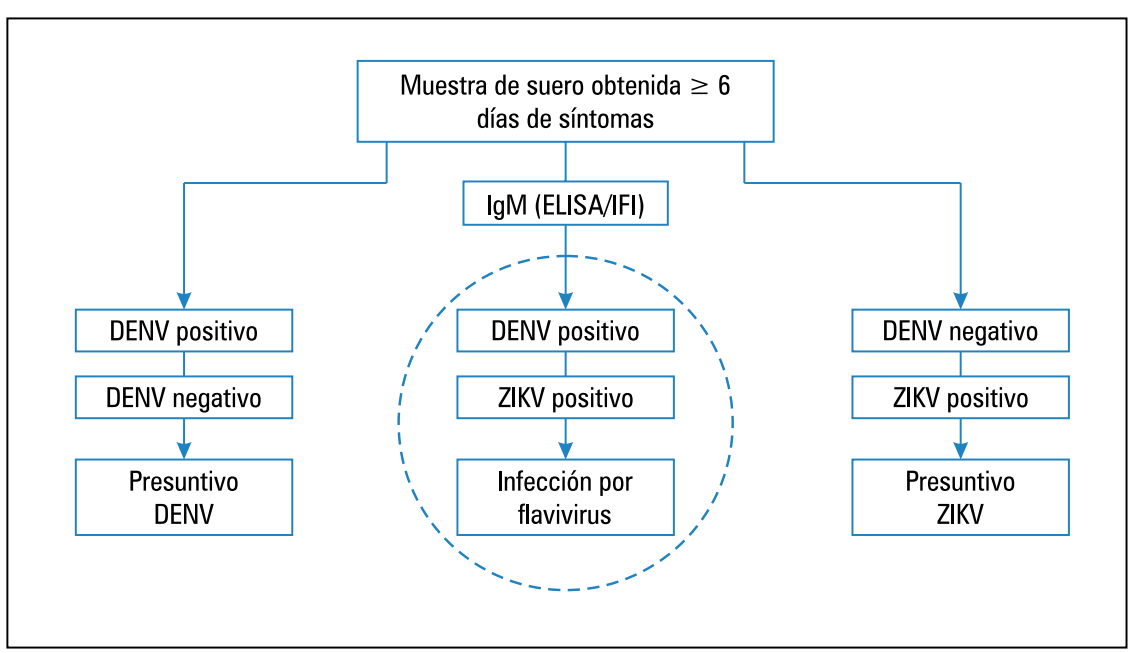

Figura 7. Algoritmo para el diagnóstico serológico de zika, cuya interpretación debe ser contextualizada ${ }^{(11)}$. ral en cultivo celular para ZIKV (a partir de muestras de orina, saliva, tejidos o sangre entera); o bien anticuerpos IgM anti-ZIKV positivos y prueba de neutralización por reducción de placa (PRNT90) para ZIKV a títulos $\geq 20$, y cuatro o más veces más alto que para otros flavivirus; y exclusión de otros flavivirus. En fallecidos, se realiza detección molecular del genoma viral a partir de tejido de autopsia, fresco o en parafina, o detección específica de antígeno viral a partir de tejido de la autopsia mediante prueba inmunohistoquímica ${ }^{(11)}$.

El caso probable de enfermedad por virus zika se define como aquel paciente que cumpla los criterios de caso sospechoso y presente también anticuerpos IgM anti-ZIKV, sin hallazgos de laboratorio que indiquen infección por otros flavivirus.

Para la determinación de ARN mediante el RT-PCR debemos considerar el tiempo de enfermedad, siendo esta prueba aplicable cuando el tiempo de enfermedad desde el inicio de los síntomas es igual o menor a 5 días (figura 4).

Estos periodos de tiempo a considerar, cuando las muestras además de suero corresponden a orina para RT-PCR y suero para determinación de anticuerpos IgM, se pueden observar en la figura 5.

Es importante tener consideraciones previas para la adecuada obtención de la muestra, que en el caso de sangre corresponde 5 a $7 \mathrm{~mL}$ en un tubo al vacío sin anticoagulante, separar el suero, trasvasarlo a dos crioviales de tapa rosca estériles de $2 \mathrm{~mL}$ y colocarlos inmediatamente a temperatura de $+2 \mathrm{a}+8{ }^{\circ} \mathrm{C}$, rotulando los crioviales con los datos del apellidos y nombres, edad, fecha de obtención de la muestra y procedencia. Si la muestra es de orina, $10 \mathrm{~mL}$. Toda muestra debe ir acompañada de su respectiva ficha clínica epidemiológica y ser enviada en cadena de frío $\left(+2 \mathrm{a}+8^{\circ} \mathrm{C}\right.$ o de ser posible con hielo seco).

En el contexto epidemiológico y con el enfoque sindrómico para el diagnóstico de las arbovirosis más frecuentes se puede aplicar el algoritmo que se muestra en la figura 6. En efecto, se puede iniciar con la determinación de ARN del dengue; 
si este resulta negativo, hacer el RT-PCR para zika, y si este resultara es negativo aplicar el procedimiento para chikungunya.

De otro lado, si el paciente tiene más de 6 días de enfermedad, donde ya no es posible detectar el ARN viral, se puede determinar el IgM y dar una interpretación adecuada, según veremos más adelante. En este caso aplicar el algoritmo que se presenta en la figura 7.

\section{REFERENCIAS BIBLIOGRÁFICAS}

1. Dick GW, Kitchen SF, Haddow AJ. Zika virus, I: Isolations and serological specificity. Trans R Soc Trop Med Hyg. 1952;46(5):509-20.

2. Duffy MR, Chen TH, Hancock WT, Powers AM, Kool JL, Lanciotti RS, Pretrick M, et al. Zika virus outbreak on Yap Island, Federated States of Micronesia. N Engl J Med. 2009;360(24):2536-43. doi: 10.1056/NEJMoa0805715.

3. Cao-Lormeau VM, Roche C, Teissier A, Robin E, Berry AL, Mallet HP, Sall AA, Musso D. Zika virus, French Polynesia, South Pacific, 2013. Emerg Infect Dis. 2014;20(6):1085-6. doi: 10.3201/ eid2010.141060

4. Zanluca C, Melo VC, Mosimann AL, Santos GI, Santos CN, Luz K. First report of autochthonous transmission of Zika virus in Brazil. Mem Inst Oswaldo Cruz. 2015 Jun;110(4):569-72. doi: 10.1590/0074-02760150192.

5. Freitas AR, Angerami RN, von Zuben AP, Donalisio MR. Introduction and transmission of Zika virus in Brazil: new challenges for the Americas. Rev Inst Med Trop Sao Paulo. 2016;58:24. doi: 10.1590/ S1678-9946201658024.

6. Gaunt MW, Sall AA, de Lamballerie X, Falconar AK, Dzhivanian TI, Gould EA. Phylogenetic relationships of flaviviruses correlate with their epidemiology, disease association and biogeography. J Gen Virol. 2001;82:1867-76.
7. Haddow AD, Schuh AJ, Yasuda CY, Kasper MR, Heang V, Huy R, Guzman H, Tesh RB, Weaver SC. Genetic characterization of Zika virus strains: geographic expansion of the Asian lineage. PLoS Negl Trop Dis. 2012;6:e1477. doi: 10.1371/journal. pntd.0001477.

8. Wang L, Valderramos SG, Wu A, Ouyang S, Li C, Brasil P, Bonaldo M, Coates T, Nielsen-Saines K. From mosquitos to humans: genetic evolution of Zika virus. Cell Host Microbe. 2016;19:561-5. doi: 10.1016/j.chom.2016.04.006

9. Lanciotti RS, Kosoy OL, Laven JJ, Velez JO, Lambert AJ, Johnson AJ, Stanfield SM, Duffy MR. Genetic and serologic properties of Zika virus associated with an epidemic, Yap State, Micronesia, 2007. Emerg Infect Dis. 2008;14:1232-9. doi: 10.3201/eid1408.080287.

10. Rabe IB, Staples JE, Villanueva J, Hummel KB, Johnson JA, Rose L; MTS, Hills S, Wasley A, Fischer $M$, Powers AM. Interim guidance for interpretation of Zika virus antibody test results. MMWR Morb Mortal Wkly Rep. 2016;65:543-6. doi: 10.15585/ mmwr.mm6521e1.

11. Guia para la vigilancia de la enfermedad por el virus del Zika y sus complicaciones. Washington, DC: OPS, 2016. [ingreso 25/10/2016) Disponible en: http://iris.paho.org/xmlui/bitstream/ handle/123456789/28234/9789275318942_spa. pdf?sequence $=1$ \&isAllowed $=y$ 